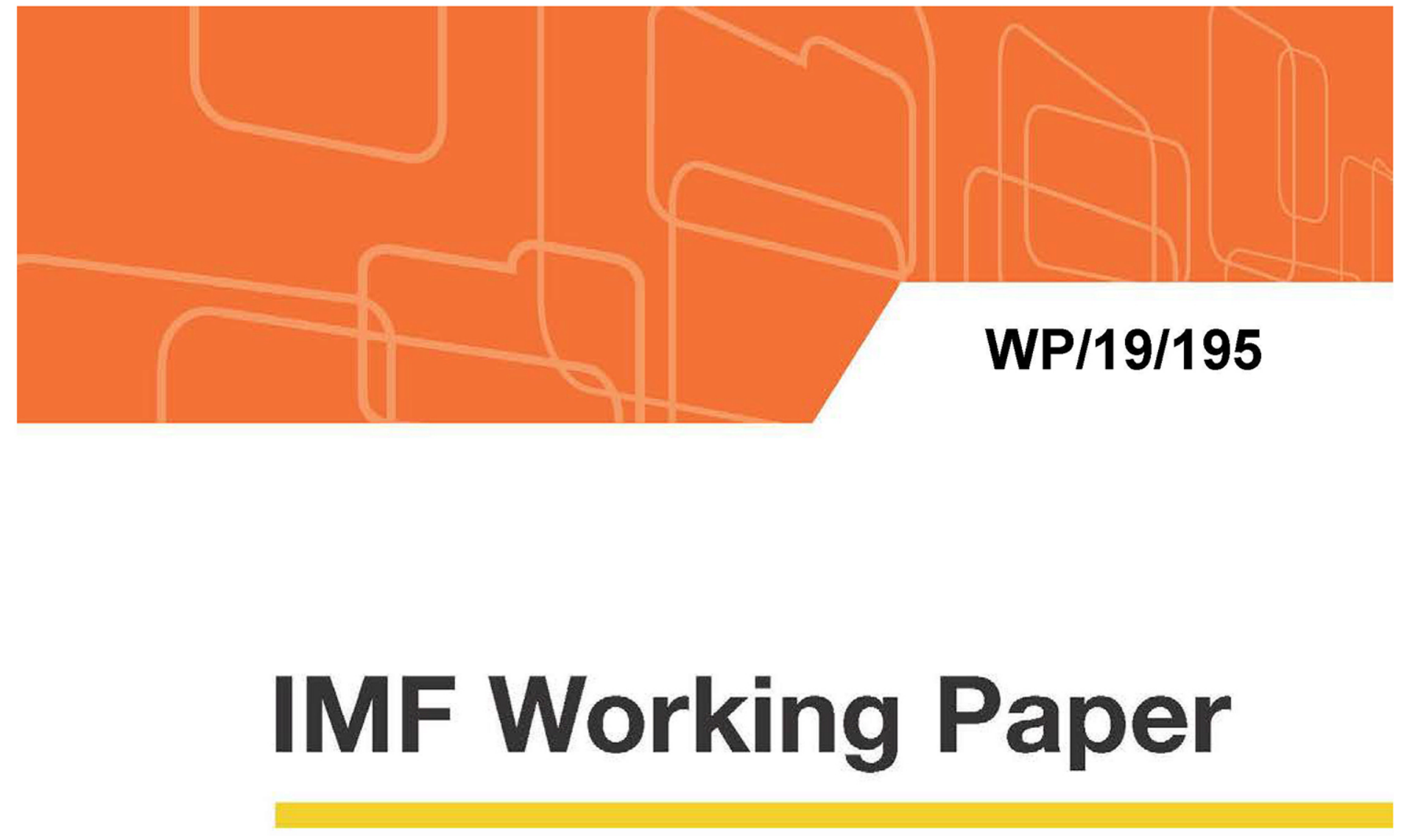

\title{
A Guide to Sovereign Debt Data
}

by S. Ali Abbas and Kenneth Rogoff, with Chengyu Huang and Kunxiang Diao

IMF Working Papers describe research in progress by the author(s) and are published to elicit comments and to encourage debate. The views expressed in IMF Working Papers are those of the author(s) and do not necessarily represent the views of the IMF, its Executive Board, or IMF management. 


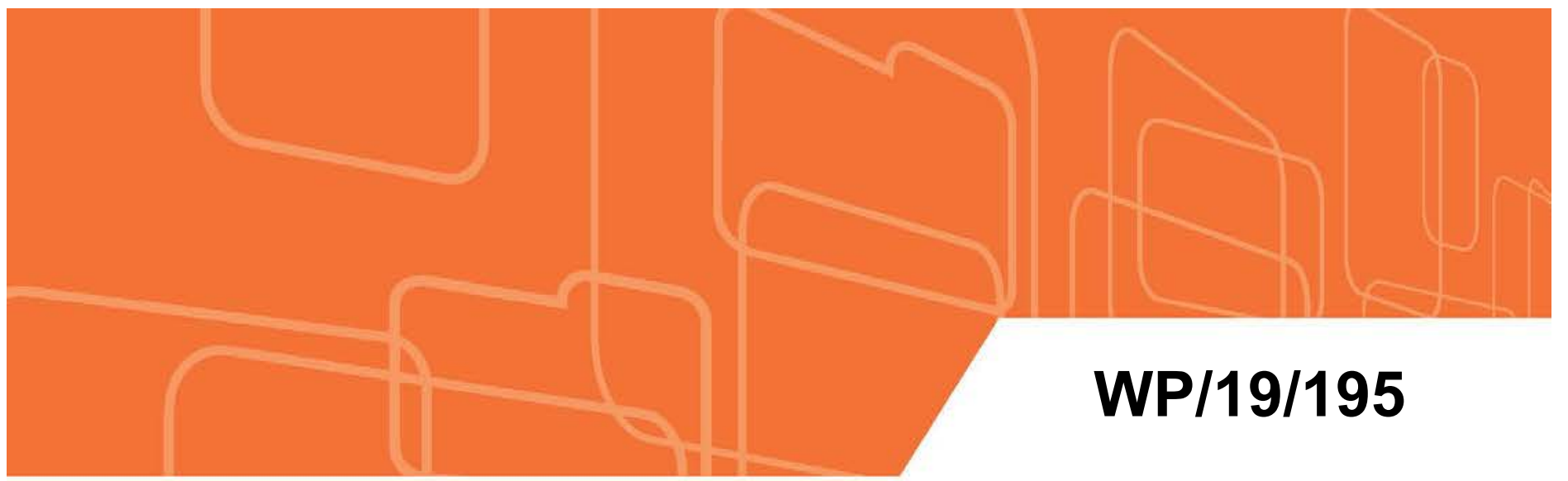

\section{IMF Working Paper}

\section{A Guide to Sovereign Debt Data}

by S. Ali Abbas and Kenneth Rogoff, with Chengyu Huang and Kunxiang Diao

IMF Working Papers describe research in progress by the author(s) and are published to elicit comments and to encourage debate. The views expressed in IMF Working Papers are those of the author(s) and do not necessarily represent the views of the IMF, its Executive Board, or IMF management.

I N T E R N A T I O N A L M O N E T A R Y F U N D 


\title{
IMF Working Paper
}

Strategy, Policy, and Review Department

\section{A Guide to Sovereign Debt Data ${ }^{1}$}

\section{Prepared by S. Ali Abbas and Kenneth Rogoff, with Chengyu Huang and Kunxiang Diao}

Authorized for distribution by Mark Flanagan

September 2019

\section{IMF Working Papers describe research in progress by the author(s) and are published to} elicit comments and to encourage debate. The views expressed in IMF Working Papers are those of the author(s) and do not necessarily represent the views of the IMF, its Executive Board, or IMF management.

\begin{abstract}
The last decade or so has seen a mushrooming of new sovereign debt databases covering long time spans for several countries. This represents an important breakthrough for economists who have long sought to, but been unable to tackle, first-order questions such as why countries have differential debt tolerance, and how debt levels affect the scope for countercyclical policy in recessions and financial crises. This paper backdrops these recent data efforts, identifying both the key innovations, as well as caveats that users should be aware of. A Directory of existing publicly-available sovereign debt databases, featuring compilations by institutions and individual researchers, is also included.
\end{abstract}

JEL-Classification Numbers: H6, H63, N1, F3.

Keywords: sovereign debt, public debt, government debt, debt statistics, historical database Author’s E-Mail Address: sabbas@imf.org, krogoff@harvard.edu, kdiao@imf.org and chuang@imf.org

\footnotetext{
${ }^{1}$ The contents of this working paper are expected to be included in the forthcoming book: S. Ali Abbas, Alex Pienkowski, and Kenneth Rogoff (eds), Sovereign Debt: A Guide for Economists and Practitioners, Oxford University Press.
} 


\section{Background}

Over the past decade, there has been a quantum leap in the development of long-dated crosscountry sovereign debt databases that has provided both important resources for researchers, as well as a more complete frame of reference for policymakers and investors. To understand issues surrounding the risks and opportunities from sovereign debt, it is important to know not only current magnitudes, maturities, and currency of denomination, but also to have extensive historical data on these same variables. Otherwise, it is extremely difficult to meaningfully ask questions such as "At what levels of debt do emerging markets begin to face high risks of losing investor confidence?, Does entering a deep recession or financial crisis with very high public debt impede a country's ability to engage in countercyclical fiscal policy?" This appendix showcases some of the resources now available.

It should be noted that although this topic received little attention from official lenders (including the International Monetary Fund (IMF)) until the 2008 financial crisis, the IMF has since devoted considerable resources and moved to the forefront of this topic (as of this writing). The IMF's new work begins with the publication of the historical debt database of Abbas and others, ${ }^{2}(2010)$ - which importantly builds on the archival research of Reinhart and Rogoff (2009in This Time is Different: Eight Centuries of Financial Folly - and, more recently, the even more ambitious IMF 2018 Global Debt Database (GDD) which now provides the most comprehensive account of private and public debt since World War II (see Mbaye, Moreno Badia, and Chae 2018). ${ }^{3}$

While it may seem hard to believe, prior to Reinhart and Rogoff's This Time is Different work (and their two earlier 2008 NBER papers), ${ }^{4}$ modern researchers had access to only extremely limited long-dated historical data on total public debt. While data on public debt issued abroad was widely available, data on domestically-issued debt was extremely sparse. Indeed, such data was not available for most advanced economies for the period before the 1980s. The problem was worse for emerging markets and low-income countries, with studies like Abbas and Christensen (2007) forced to use banking system claims on government as a

\footnotetext{
2“A Historical Public Debt Database," IMF Working Paper 10/245, also published as "Historical Patterns and Dynamics of Public Debt_Evidence From a New Database," IMF Economic Review, Volume 59, Issue 4.

3"The Global Debt Database: Methodology and Sources," IMF Working Paper 18/111. For the data, see https://www.imf.org/en/Publications/WP/Issues/2018/05/14/Global-Debt-Database-Methodology-and-Sources45838. The GDD aims to address several shortcomings of previous databases. First, it takes a fundamentally new approach to compiling historical data. The GDD adopts a multidimensional approach by offering multiple debt series with different coverages, thus ensuring greater consistency across time. Second, it more than doubles the cross-sectional dimension of existing private debt datasets. Finally, the integrity of the data has been checked through bilateral consultations with officials and IMF country desks of all countries in the sample.

4"This Time is Different: A Panoramic View of Eight Centuries of Financial Crises," NBER Working Paper 13882; and "The Forgotten History of Domestic Debt," NBER Working Paper No. 13946.
} 
proxy. ${ }^{5}$ This fact (which was first emphasized in Reinhart, Rogoff, and Savastano 2003) may sound incredible to those who are not empirical researchers using macroeconomic data. ${ }^{6}$ The reasons why the data was not better kept are something of a mystery, but it is nevertheless true that long-dated historical data on domestically-issued public debt and, hence, total public debt, was not available in any standard source, even the debt time series published by the IMF or the World Bank. ${ }^{7}$

This lack of historical debt data was a huge omission that, as Reinhart and Rogoff (2009) (and in several related papers) showed, led to a blind spot in research in many areas, for example, the risks of sovereign debt crisis, and the genesis of very high inflation. Importantly, Reinhart and Rogoff (2009) contained extensive documentation of data sources for constructing long-dated time series on public debt, both domestically-issued and issued abroad, offering a blueprint for replication and extensions, including the IMF's important research that followed. As Reinhart and Rogoff discuss, and as others have since replicated, a critical archival source turned out to be old volumes of the League of Nations. One fact Reinhart and Rogoff found was that, contrary to widespread belief, many emerging markets, including in Latin America, had been able to issue in earlier decades large quantities of longterm debt denominated in their own currencies. For many of these countries, therefore, the problem of "original sin" actually started with the hyperinflations of the 1980s and 1990s.

Another major gap in the data concerned the currency composition of debt. Even for debt issued abroad, data on currency of denomination had been very limited, except for the modern period (as for example the data employed in Bevilaqua, Bulow, and Rogoff, 1992). ${ }^{8}$ But, again, recent work by IMF economists (notably Abbas and others, 2014) has taken large strides in remedying this situation by providing extensive data on both currency of denomination and maturity, data that allows far more nuanced analyses of debt vulnerabilities than was previously possible. ${ }^{9}$

More recently, there have been many other important advances, as embodied in the data sets listed below. Importantly, the databases listed in this appendix are all associated with careful scholarly research. Whereas they have been integral to construction of the IMF's GDD, they are of particular use for researchers precisely because there are typically associated research

\footnotetext{
5"The Role of Domestic Debt Markets in Economic Growth: An Empirical Investigation for Low-Income Countries and Emerging Markets,” IMF Working Paper 07/127.

6“Debt Intolerance," NBER Working Paper No. 9908.

${ }^{7}$ One explanation that is sometime presented is that, until the $1980 \mathrm{~s} / 1990 \mathrm{~s}$, many countries did not have modern debt management offices that would collect all debt data; and that these functions remained segregated in different parts of the finance ministries/central banks. However, this cannot fully explain why total public debt coverage was relatively good in the inter-war period, the lack of incentive to institute dedicated debt management offices till the 1980s, or why international financial institutions did not put greater priority on catalyzing the collection of historical domestic debt data.

8“Official Creditor Seniority and Burden Sharing in the Former Soviet Bloc," Brookings Papers in Economic Activity 1.

9“'Sovereign Debt Composition in Advance Economies: A Historical Perspective,” IMF Working Paper 14/162.
} 
papers with detailed discussion and documentation that aid an understanding of the data, and potentially allow a check of the decisions made in constructing it by making reference to the original sources.

Caveat emptor: Tedious historical and archival research lies at the heart of many of these new data sets; it is hard enough to decide how to measure contemporaneous debt (for example, should the central bank and central government balance sheet be integrated?, how does one account for the debt of state-owned enterprises, how does one account for government assets?, what about unfunded pension liabilities?) but historical ones are more difficult, particularly in the many cases where the data had effectively been lost or forgotten until recently - a widespread problem with public debt data. And the problems just increase when one wants to bring in other variables, for example, in forming debt/GDP ratios. Although some researchers seem blithely unaware of the fact, Gross Domestic Product is in fact a relatively modern construct, developed by Simon Kuznets and his collaborators in the mid-1930s. Economic historians have done very important work trying to artificially reconstruct historical data (most famously, the work of the late Angus Madison who curated data from many other researchers, https://www.rug.nl/ggdc/historicaldevelopment/maddison/), but there are huge gaps and many assumptions are required. Indeed, even many of today's advanced economies took many years after the Second World War to build up their statistical capabilities so that for quite a few states data before 1955 can be unreliable, and for some this is the case going into the 1960s.

A second important caveat relates to cross-country and time series comparability of debt data. Because researchers have an interest in developing long time series for as many countries as possible, they often make expedient decisions regarding inclusion/exclusion of data that can result in statistical inconsistencies: for instance, a long debt series for an individual country may concatenate central government debt in the early years with general government debt in later years (an issue made transparent in Mauro and others, 2013); ${ }^{10}$ or public debt numbers can be reported for two sovereigns for the same year but without noting the differences in instrument coverage, valuation basis, and netting of assets. ${ }^{11}$

With this background, readers should be able to better appreciate both the major gaps in sovereign debt data, as well as the important advances recently made by institutions and researchers to address those gaps. The Directory of Sovereign Debt Databases that follows provides a state-of-play on these advances, by providing a listing of known sovereign debt datasets currently available for use by researchers and practitioners.

\footnotetext{
10“'A Modern History of Fiscal Prudence and Profligacy,” IMF Working Paper No. 13/5, International Monetary Fund, Washington, DC.

${ }^{11}$ To be able to analyze and balance the competing considerations of larger sample and comparability, and to appropriately qualify their conclusions, researchers may find useful the international methodological standards on compiling public sector debt (e.g., the IMF's Public Sector Debt Statistics Guide for Compilers and Users, 2013 and Government Finance Statistics Manual 2014).
} 
Appendix Table 1 provides a tabular summary of the databases included in the Directory. These are listed in alphabetical order and subdivided into two broad categories: Researcher databases, and Institutional databases. For each database, information is provided on time and country coverage; as well on the types of variables included; these broadly fall into four categories: debt-to-GDP levels, debt structure (currency, maturity, holder profile); crises/restructurings; and other public finance.

\section{Appendix Table 1: Summary of Sovereign Debt Databases}

\begin{tabular}{|c|c|c|c|c|c|c|c|}
\hline No. & $\begin{array}{l}\text { Researchers/ } \\
\text { Institution }\end{array}$ & Name of database & $\begin{array}{l}\text { Coverage } \\
\text { (years } \\
\text { countries) }\end{array}$ & $\begin{array}{r}\text { Debt- } \\
\text { to- } \\
\text { GDP }\end{array}$ & $\begin{array}{r}\text { Debt } \\
\text { structure }\end{array}$ & $\begin{array}{r}\text { Crises/ } \\
\text { Restruct- } \\
\text { urings }\end{array}$ & $\begin{array}{r}\text { Other } \\
\text { public } \\
\text { finance }\end{array}$ \\
\hline \multicolumn{8}{|c|}{ Researcher Databases } \\
\hline 1 & $\begin{array}{l}\text { Abbas, Belhocine, } \\
\text { El-Ganainy \& } \\
\text { Horton }\end{array}$ & $\begin{array}{l}\text { A Historical Public Debt } \\
\text { Database }\end{array}$ & $\begin{array}{c}1692-2018 \\
178 \text { economies }\end{array}$ & $\sqrt{ }$ & $\sqrt{ }$ & & \\
\hline 2 & $\begin{array}{c}\text { Abbas \& } \\
\text { Christensen }\end{array}$ & $\begin{array}{l}\text { The Role of Domestic Debt } \\
\text { Markets in Economic Growth }\end{array}$ & $\begin{array}{l}1970-2007 \\
93 \text { EMLICs }\end{array}$ & $\sqrt{ }$ & & & \\
\hline 3 & $\begin{array}{c}\text { Abbas, Blattner, De } \\
\text { Broeck, El-Ganainy } \\
\& \mathrm{Hu}\end{array}$ & $\begin{array}{l}\text { Sovereign Debt Composition } \\
\text { in Advanced Economies }\end{array}$ & $\begin{array}{l}1900-2011 \\
13 \text { AEs }\end{array}$ & $\sqrt{ }$ & $\sqrt{ }$ & & $\sqrt{ }$ \\
\hline 4 & Arslanalp \& Tsuda & $\begin{array}{l}\text { Tracking Global Demand for } \\
\text { Sovereign Debt }\end{array}$ & $\begin{array}{c}2004-17 \\
24 \text { EMs and } 24 \\
\text { AEs }\end{array}$ & $\sqrt{ }$ & $\sqrt{ }$ & & $\sqrt{ }$ \\
\hline 5 & $\begin{array}{c}\text { Beck, Demirguc- } \\
\text { Kunt, Levine, Cihak } \\
\text { \& Feyen }\end{array}$ & Financial Structure Database & $\begin{array}{c}1960-2017 \\
214 \text { economies }\end{array}$ & $\sqrt{1}$ & $\sqrt{ }$ & & \\
\hline 6 & Cruces \& Trebesch & $\begin{array}{l}\text { Sovereign Defaults: The Price } \\
\text { of Haircuts }\end{array}$ & $\begin{array}{c}1970-2013 \\
72 \text { economies }\end{array}$ & & & $\sqrt{ }$ & \\
\hline 7 & $\begin{array}{l}\text { Hall, Payne and } \\
\text { Sargent }\end{array}$ & $\begin{array}{c}\text { US Federal Debt 1776-1960: } \\
\text { Quantities and Price }\end{array}$ & $\begin{array}{c}1776-1960 \\
\text { United States }\end{array}$ & & & & $\sqrt{ }$ \\
\hline 8 & $\begin{array}{l}\text { Jaimovich \& } \\
\text { Panizza }\end{array}$ & Public Debt around the World & $\begin{array}{c}1991-2005 \\
96 \text { economies }\end{array}$ & $\sqrt{ }$ & $\sqrt{ }$ & & \\
\hline 9 & Jeanne \& Guscina & $\begin{array}{c}\text { Government Debt in } \\
\text { Emerging Market Countries }\end{array}$ & $\begin{array}{l}1980-2013 \\
19 \mathrm{EMs}\end{array}$ & $\sqrt{ }$ & $\sqrt{ }$ & & \\
\hline 10 & $\begin{array}{c}\text { Kaminsky \& Vega- } \\
\text { Garcia }\end{array}$ & $\begin{array}{l}\text { Systemic and Idiosyncratic } \\
\text { Sovereign Debt Crises }\end{array}$ & $\begin{array}{c}1800-1960 \\
7 \text { LatAm EMs }\end{array}$ & $\sqrt{ }$ & & & \\
\hline 11 & $\begin{array}{l}\text { Mauro, Romeu, } \\
\text { Binder \& Zaman }\end{array}$ & $\begin{array}{l}\text { A Modern History of Fiscal } \\
\text { Prudence and Profligacy }\end{array}$ & $\begin{array}{c}1800-2011 \\
24 \text { AEs, } 31 \\
\text { EMLICs }\end{array}$ & $\sqrt{ }$ & $\sqrt{ }$ & & $\sqrt{ }$ \\
\hline 12 & $\begin{array}{l}\text { Merler \& Pisani- } \\
\text { Ferry }\end{array}$ & $\begin{array}{c}\text { Bruegel Database of } \\
\text { Sovereign Bond Holdings }\end{array}$ & $\begin{array}{c}\text { 1995-2017 } \\
12 \text { EC states; US }\end{array}$ & $\sqrt{ }$ & & & $\sqrt{ }$ \\
\hline 13 & Panizza & $\begin{array}{l}\text { Domestic and External Public } \\
\text { Debt in Developing Countries }\end{array}$ & $\begin{array}{c}1990-2007 \\
130 \text { economies }\end{array}$ & $\sqrt{ }$ & & & $\sqrt{ }$ \\
\hline 14 & Presbitero & $\begin{array}{l}\text { Domestic Debt in Low- } \\
\text { income Countries }\end{array}$ & $\begin{array}{c}1970-2010 \\
44 \text { LICs }\end{array}$ & $\sqrt{ }$ & & & \\
\hline 15 & Reinhart & $\begin{array}{c}\text { Dates for Banking Crises, } \\
\text { Currency Crashes, Sovereign } \\
\text { Domestic or External Default } \\
\text { (or Restructuring), Inflation } \\
\text { Crises, and Stock Market } \\
\text { Crashes (Varieties) }\end{array}$ & $\begin{array}{c}1800-2010 \\
70 \text { economies }\end{array}$ & & & $\sqrt{ }$ & $\sqrt{ }$ \\
\hline 16 & Reinhart & Debt-to-GDP Ratios & $\begin{array}{c}1692-2010 \\
70 \text { economies }\end{array}$ & $\sqrt{ }$ & $\sqrt{ }$ & & \\
\hline 17 & Reinhart \& Rogoff & This Time Is Different & $\begin{array}{c}1800-2017 \\
\text { varies by dataset }\end{array}$ & $\sqrt{ }$ & & & $\sqrt{ }$ \\
\hline 18 & Scott & $\begin{array}{c}\text { Manageing the UK National } \\
\text { Debt } 1694-2018\end{array}$ & $\begin{array}{c}1694-2018 \\
\text { United Kingdom }\end{array}$ & $\sqrt{ }$ & & & $\sqrt{ }$ \\
\hline
\end{tabular}




\section{Appendix Table 1. Summary of Sovereign Debt Databases (concluded)}

\begin{tabular}{|c|c|c|c|c|c|c|c|}
\hline No. & $\begin{array}{l}\text { Researchers/ } \\
\text { Institution }\end{array}$ & Name of database & $\begin{array}{l}\text { Coverage } \\
\text { (years } \\
\text { countries) } \\
\end{array}$ & $\begin{array}{r}\text { Debt- } \\
\text { to- } \\
\text { GDP } \\
\end{array}$ & $\begin{array}{r}\text { Debt } \\
\text { structure }\end{array}$ & $\begin{array}{r}\text { Crises/ } \\
\text { Restruct- } \\
\text { urings } \\
\end{array}$ & $\begin{array}{r}\text { Other } \\
\text { public } \\
\text { finance }\end{array}$ \\
\hline \multicolumn{8}{|c|}{ Institutional Databases } \\
\hline 19 & BIS & Debt Securities & $\begin{array}{c}1952 \text {-present } \\
157 \text { economies }\end{array}$ & $\sqrt{ }$ & $\sqrt{ }$ & & $\sqrt{ }$ \\
\hline 20 & Bank of Canada & Sovereign Default & $\begin{array}{c}1960-2017 \\
145 \text { economies }\end{array}$ & & & $\sqrt{ }$ & $\sqrt{ }$ \\
\hline 21 & ECB & $\begin{array}{l}\text { Debt securities issuance and } \\
\text { service by EU government }\end{array}$ & $\begin{array}{c}\text { 2016-present } \\
28 \mathrm{EU} \\
\text { economies }\end{array}$ & & $\sqrt{ }$ & & $\sqrt{ }$ \\
\hline 22 & IDB & Living with Debt & $\begin{array}{l}\text { 1980-2013 } \\
\text { 26 LatAm }\end{array}$ & $\sqrt{ }$ & $\sqrt{ }$ & & \\
\hline 23 & IDB & $\begin{array}{l}\text { Standardized Public Debt } \\
\text { Database }\end{array}$ & $\begin{array}{c}\text { 2006-16 } \\
\text { 26 LatAm }\end{array}$ & $\sqrt{ }$ & $\sqrt{ }$ & & $\sqrt{ }$ \\
\hline 24 & $\mathrm{IMF}$ & Fiscal Monitor & $\begin{array}{c}\text { 2010-present } \\
115 \text { economies }\end{array}$ & $\sqrt{ }$ & $\sqrt{ }$ & & $\sqrt{ }$ \\
\hline 25 & IMF & Global Debt Database & $\begin{array}{c}1950-2017 \\
190 \text { economies }\end{array}$ & $\sqrt{ }$ & $\sqrt{ }$ & & $\sqrt{ }$ \\
\hline 26 & IMF & $\begin{array}{l}\text { International Financial } \\
\text { Statistics }\end{array}$ & $\begin{array}{c}2000 \text {-present } \\
194 \text { economies }\end{array}$ & $\sqrt{ }$ & $\sqrt{ }$ & & $\sqrt{ }$ \\
\hline 27 & $\mathrm{IMF}$ & $\begin{array}{l}\text { Public Sector Balance Sheet } \\
\text { (PSBS) }\end{array}$ & $\begin{array}{l}\text { 2000-present } \\
38 \text { economies }\end{array}$ & $\sqrt{ }$ & $\sqrt{ }$ & & $\sqrt{ }$ \\
\hline 28 & IMF & $\begin{array}{l}\text { World Economic Outlook } \\
\text { (WEO) }\end{array}$ & $\begin{array}{c}1980-2000 \\
199 \text { economies }\end{array}$ & $\sqrt{ }$ & $\sqrt{ }$ & & \\
\hline 29 & OECD & General Government Debt & $\begin{array}{c}1995-2017 \\
\text { OECD members } \\
\end{array}$ & $\sqrt{ }$ & $\sqrt{ }$ & & $\sqrt{ }$ \\
\hline 30 & World Bank & $\begin{array}{l}\text { International Debt Statistics } \\
\text { (IDS) }\end{array}$ & $\begin{array}{c}1970-2016 \\
\text { Mostly EMLICs }\end{array}$ & $\sqrt{ }$ & $\sqrt{ }$ & & $\sqrt{ }$ \\
\hline 31 & World Bank & $\begin{array}{l}\text { Quarterly External Debt } \\
\text { Statistics (QEDS) }\end{array}$ & $\begin{array}{l}\text { 1998-present } \\
40 \text { EMLICs }\end{array}$ & $\sqrt{ }$ & $\sqrt{ }$ & & $\sqrt{ }$ \\
\hline 32 & World Bank & $\begin{array}{l}\text { Quaterly Public Sector Debt } \\
\text { (QPSD) }\end{array}$ & $\begin{array}{l}\text { 1995-present } \\
40 \text { EMLICs }\end{array}$ & $\sqrt{ }$ & $\sqrt{ }$ & & $\sqrt{ }$ \\
\hline
\end{tabular}

* AEs = Advanced Economies; EMs = Emerging Markets; EMLICs = emerging markets and low-income countries; LatAm = Latin America; EC = European Commission, ECB = European Central Bank, BIS = Bank for International Settlements; IDB = Inter-American Development Bank; IMF = International Monetary Fund.

\section{Directory of Sovereign Debt Databases}

(as of September 2018)

\section{A. Researcher Databases}

\section{1. “A Historical Public Debt Database," IMF Working Paper No. 10/245, International Monetary Fund, Washington, DC ${ }^{12}$}

Authors: S. M. Ali Abbas, Nazim Belhocine, Asmaa El-Ganainy, and Mark Horton

Website: https://www.imf.org/ /media/Websites/IMF/importeddatasets/external/pubs/ft/wp/2010/Data/ wp10245.ashx

Description: This database provides a very long time series of debt-to-GDP ratios for almost all IMF member countries. The earliest data point starts from 1692. Most G-7 countries and a few other advanced countries are covered since 1880 and the general coverage starts from

${ }^{12}$ Also published as "Historical Patterns and Dynamics of Public Debt—Evidence From a New Database," IMF Economic Review Volume 59, Issue 4. 
1970. The database is compiled by combing various cross-country databases such as the IMF's World Economic Output and Statistical Handbooks from The League of Nations and the United Nations. Other official government publications and databases compiled by other previous researchers are also used.

Notes for researchers: This database aims to provide general government debt-to-GDP ratios. However, in a lot of cases (especially for the period before 1980), central government data was reported where data for general government was not available. Also, in the database, debt is scaled to nominal GDP. However, GNP and NNP were used when GDP was not available. Some data smoothing was applied when transiting from one source to another, but larger breaks were indicated in the database. This database does not disaggregate public debt into external and domestic.

Country coverage: 178 countries

Time coverage: $1692-2018$ (partial coverage)

Frequency: Annual

\section{2. "The Role of Domestic Debt Markets in Economic Growth: An Empirical Investigation for Low-Income Countries and Emerging Markets"}

Authors: S. M. Ali Abbas and Jakob E. Christensen

Website: https://www.imf.org/en/Publications/WP/Issues/2016/12/31/The-Role-ofDomestic-Debt-Markets-in-Economic-Growth-An-Empirical-Investigation-for-Low-20973 (contact SAbbas@imf.org for data)

Description: In this database domestic debt is defined as domestic currency debt owed to domestic citizens and as commercial bank's gross claims on the Central Government plus central bank liquidity paper. The dataset excludes government debt held by retail investors and non-banking institutions.

Country coverage: 93 low-income countries (LIC) and emerging markets

Time coverage: 1970-2007

Frequency: Annual

\section{3. "Sovereign Debt Composition in Advanced Economies: A Historical Perspective," IMF Working Paper No. 14/162, International Monetary Fund, Washington, DC}

Authors: S. M. Ali Abbas, Laura Blattner, Mark De Broeck, Asmaa El-Ganainy, and Malin $\mathrm{Hu}$

Website: http://www.imf.org/en/Publications/WP/Issues/2016/12/31/Sovereign-DebtComposition-in-Advanced-Economies-A-Historical-Perspective-41899

Description: This data set examines the composition of sovereign debt in thirteen advanced economies from 1900 to 2011 (Australia, Belgium, Canada, France, Germany, Ireland, Italy, Japan, Netherlands, Spain, Sweden, United States, United Kingdom). It is broken down by currency, maturity, holder profile, and marketability. It provides valuable insights into sovereign debt structure trends over the last century. 
Notes for researchers: Each debt component (by currency, maturity, holder profile and marketability) is scaled to central government debt, except for Australia (sum of commonwealth and state debt) and Italy (general government debt). The construction of long series requiring combining data from different sources which in a number of cases resulted in significant breaks in the series (e.g., Australian data in 1950). In some other cases data is available but was not included in the data set as further verification of their accuracy is needed (e.g., German debt composition data for the initial post-Second World War years).

Country coverage: 13 advanced economies

Time coverage: 1900-2011

Frequency: Annual

\section{4. "Tracking Global Demand for Sovereign Debt," IMF Working Paper WP/14/39 (and WP/12/284), International Monetary Fund, Washington, DC}

Authors: Serkan Arslanalp and Takahiro Tsuda

Website: https://www.imf.org/en/Publications/WP/Issues/2016/12/31/Tracking-GlobalDemand-for-Emerging-Market-Sovereign-Debt-41399

https://www.imf.org/en/Publications/WP/Issues/2016/12/31/Tracking-Global-Demand-forAdvanced-Economy-Sovereign-Debt-40135

Description: The data set provides estimates of investor holdings of government debt of twenty-four emerging market economies and twenty-four major advanced economies. The investor base is grouped into six classes: domestic central bank, domestic banks, domestic nonbanks, foreign official sector, foreign banks, and foreign nonbanks. All data are either in face value or adjusted for valuation changes, where appropriate, to remove price revaluations.

Notes for researchers: This database is a consolidation of multiple debt databases (including International Financial Statistics (IFS), Bank of International Settlement (BIS), European Central Bank (ECB), Eurostat, Consolidated Portfolio Investment Survey (CPIS), Currency Composition of Official Foreign Exchange Reserves (COFER), and Quarterly External Debt Statistics (QEDS)) with authors' estimations. It is subject to various measurement errors. (1) Estimates for foreign central banks' holdings may be understated. In this paper, foreign central banks' holdings are the sum of government securities held by foreign central banks as reserve assets and foreign official loans and the data is largely based on IMF's COFFER and CPIS. Other types of foreign assets that are not included as reserve assets are not included in this calculation. (2) Estimates for foreign bank holdings rely on BIS locational banking statistics. In that sense, some of those estimates may be overstated for countries where there is a large difference between locational and consolidated BIS statistics. (3) Foreign and domestic nonbanks are calculated as implied values in this paper which may include measurement errors.

Country coverage: 24 Emerging markets and 24 advanced economies

Time coverage: $2004-18$

Frequency: Quarterly 


\section{5. "Financial Structure Database"}

Authors: Thorsten Beck, Asli Demirguc-Kunt, Ross Eric Levine, Martin Cihak and Erik H.B. Feyen

Website: https://www.worldbank.org/en/publication/gfdr/data/financial-structure-database

Description: This dataset is not focused on sovereign debt data but captures various aspects of financial institutions and markets that could be very useful for researchers, including: public/private bond market capitalization to GDP; international debt issues to GDP, loans from non-resident banks (net/AMT outstanding) to GDP.

Country coverage: 214 countries

Time coverage: 1960-2017

Frequency: Annual

\section{6. "Sovereign Defaults: The Price of Haircuts"}

Authors: Juan Cruces and Christoph Trebesch

Website: https://sites.google.com/site/christophtrebesch/data

Description: This database provides a list of restructuring events of public and publiclyguaranteed debt owed to foreign private creditors. Among the most important variables, the database contains debt restructure; preferred haircut; market haircut; face value reduction; and bond exchange. Also, the authors provide haircut estimates and further information on each arrangement.

Notes for researchers: The selection of restructuring cases is based on five criteria:

(1) Public or publicly-guaranteed debt restructurings; (2) restructurings with foreign private creditors are included; (3) distressed debt exchanges; (4) medium- and long-term restructurings; and (5) restructurings that are implemented.

Country coverage: 72 countries (all countries that restructured debt)

Time coverage: $1970-2013$

Frequency: Date of occurrence

\section{7. "US Federal Debt 1776-1960: Quantities and Price"}

Authors: George Hall, Jonathan Payne and Thomas Sargent

Website: https://github.com/jepayne/US-Federal-Debt-Public

Description: This database provides prices, quantities, and descriptions of all securities issued by the US Treasury between 1776 and 1960. It contains descriptions of every individual Treasure bonds and notes; times series data on the quantity outstanding for each bond and times series data on the market price for each bond.

Notes for researchers: Data is released on github with some basic instructions on how to use them in python. More detailed description is available at:

http://www.tomsargent.com/research/ReadMe_Pub.pdf 
Country coverage: United States

Time coverage: $1776-1960$

Frequency: Monthly

\section{8. "Public Debt around the World: A New Dataset of Central Government Debt"}

Authors: Dany Jaimovich, and Ugo Panizza

Website: https://www.tandfonline.com/doi/abs/10.1080/13504850701719785

Description: This database presents a complete series of central government debt for eightynine countries including all the major economies except the Eastern European Transition States over the 1991-2005 period and for seven other countries for the 1993-2005 period.

Notes for researchers: In this database, public debt is defined as gross central government debt. Although, most of the data is from official sources, due to different fiscal centralization level, the exact reporting standard can still vary from country to country.

Country coverage: 96 countries

Time coverage: $1991-2005$

Frequency: Annual (partially covered)

\section{9. "Government Debt in Emerging Market Countries: A New Data Set"}

Authors: Olivier Jeanne and Anastasia Guscina

Website: https://www.imf.org/en/Publications/WP/Issues/2016/12/31/Government-Debt-inEmerging-Market-Countries-A-New-Data-Set-18923 (contact AGuscina@imf.org for data)

Description: This database provides extensive information related to the size and structure of central government debt. This information is divided into domestic and foreign debt by jurisdiction of issuance. Domestic debt is decomposed by maturity at issuance (short-term, medium-term, or long-term), fixed or variable interest rate; local currency or foreign currency, nominal or CPI-indexed. Foreign debt is decomposed by private creditors or official creditors. Finally, the share of FX debt (and USD in particular) in foreign debt is also included.

Notes for researchers: The data only covers central government debt due to the difficulties of finding state-owned enterprise or local government debt. Also, the domestic debt of central banks is, for the most part, not included since the number is small. The definition of domestic debt is domestically issued debt in this database, and international debt means debt issued overseas.

Country coverage: 19 emerging countries

Time coverage: $1980-2013$

Frequency: Annual

10. "Systemic and Idiosyncratic Sovereign Debt Crises-Database"

Authors: Graciela Kaminsky and Pablo Vega-García 
Website: https://www.gracielakaminsky.com/databases

Description: The authors compiled information for six data series: exports (in British pounds), terms of trade $(1900=100)$, international issuance relative to U.K. export trend, world imports (in British pounds), U.K. real interest rate, and debt service relative to the U.K. export trend.

Notes for researchers: The database captures data from 1800 to 1960, and data are presented in British pounds. Researchers should notice that Argentina, Brazil, and Chile started reporting export data since the early nineteenth century. But export data for Colombia, Peru, Mexico, and Uruguay are derived by using mirrored data of their main trading partners in the nineteenth century.

Country coverage: 7 countries (Argentina, Brazil, Chile, Colombia, Mexico, Peru, and Uruguay)

Time coverage: $1800-1960$ (partially covered)

Frequency: Annual

\section{1. "A Modern History of Fiscal Prudence and Profligacy," IMF Working Paper No. 13/5, International Monetary Fund, Washington, DC}

Authors: Paolo Mauro, Rafael Romeu, Ariel Binder and Asad Zaman

Website: https://www.imf.org/en/Publications/WP/Issues/2016/12/31/A-Modern-History-ofFiscal-Prudence-and-Profligacy-40222

Description: This database provides very long time series on various fiscal variables for a wide range of countries. It covers not only public debt stock but also the related fiscal balance and its subcomponents. Specifically, the dataset includes fiscal revenues, primary expenditures, government debt, interest paid on public debt and gross domestic product for fifty-five countries and for up to two hundred years. About half of the data came from publicly available cross-country sources such as IMF's World Economic Outlook, International Financial Statistics, OECD Analytical Database, the Statistical Yearbooks of the League of Nations, Montevideo-Oxford Latin American Database, and some previous work done by Marc Flandreau, Frèdèric Zumer and Brian Mitchell. The other half of the data is collected from country-specific sources.

Notes for researchers: Coverage of the government sector varies from country to country mainly due to data limitations. The site reports at general government level where data was available. However, in most cases, general government data is difficult to collect for earlier years. In that sense, most observations before the 1960s cover only central government and latter switched to general government. Structural breaks are expected generally in the $1960 \mathrm{~s}$ and 1970s. Those breaks are recorded in dummy variables.

Country coverage: 55 countries ( 24 advanced economies and 31 emerging and low-income economies)

Time coverage: $1800-2011$

Frequency: Annual 


\section{2. "Bruegel Database of Sovereign Bond Holdings"}

Authors: Silvia Merler and Jean Pisani-Ferry

Website: http://bruegel.org/publications/datasets/sovereign-bond-holdings/

Description: This database reports the quarterly and annually sovereign bond holding (resident banks, non-residents) as a share of total sovereign bond holdings across twelve European countries and the United States.

Notes for researchers: The database covers the sectorial holding of sovereign bonds for Belgium, Finland, France, Germany, Greece, Ireland, Italy, Netherlands, Portugal, Spain, United Kingdom, and United States. Quarterly data are available from 1997 to 2017. And the data are standardized and reclassified based on five categories (banks, central banks, public institutions, other resident sectors, and non-resident holders). The primary source of the data is the ECB, and national sources are used when data is not available in the ECB.

Country coverage: 12 European countries and the United States

Time coverage: 1995-2017

Frequency: Quarterly data from December 1997 to March 2017. Annual data from 1995 to 2016.

\section{3. "Domestic and External Public Debt in Developing Countries"}

Authors: Ugo Panizza

Website: http://debt-and-finance.unctad.org/Documents/Discussionpapers/Domestic and_External_Public_Debt in_Developing_Countries_PANIZZA_2008.pd $\underline{f}$ (contact the authors for data)

Description: This database provides data on total public debt (external and domestic). Public debt data is collected from different sources and liabilities included in the definition might differ across countries. Public sector definition and liabilities differ across countries.

Notes for researchers: The database covers 130 countries from 1990 to 2007, but 2006 and 2007 data are either forecasts or preliminary estimates. As a result, the coverage is weak in these two years. The author used the central government debt in most cases, but general government and nonfinancial public sector debt data is used when the central government data is not available.

Country coverage: 130 countries

Time coverage: 1990-2007

Frequency: Annual

\section{4. "Domestic Debt in Low-income Countries"}

Authors: Andrea F. Presbitero

Website: https://sites.google.com/site/presbitero/homepage/data 
Description: This database provides data on the stock of domestic public debt, collected from various previous works. It covers forty-four low-income countries for the period 19702010.

Notes for researchers: The exact definition of domestic debt is very burly. In most cases, it is defined as the total public debt subtracted by public external debt. But the exact definition can vary based on data sources.

Country coverage: 44 low-income countries

Time coverage: $1970-2010$

Frequency: Annual

\section{5. "Dates for Banking Crises, Currency Crashes, Sovereign Domestic or External Default (or Restructuring), Inflation Crises, and Stock Market Crashes (Varieties)"}

Authors: Carmen M. Reinhart

Website: http://www.carmenreinhart.com/data/browse-by-topic/topics/7/

Description: This database includes five series data for a variety of financial crises: currency crisis, inflation crisis, stock market crisis, sovereign domestic debt crisis, sovereign external debt crisis, and banking crisis. Stock market crashes are included for a smaller set of countries subject to equity price data availability. Finally, the author includes two data series: a yearly tally of crises "varieties" and a dummy variable indicating the year of independence (if applicable). This database is an extension of Reinhart and Rogoff's earlier work published in 2008 "This Time is Different: A Panoramic View of Eight Centuries of Financial Crisis" https://www.nber.org/papers/w13882.

Notes for researchers: The database covers crises varieties from 1800 to 2010. Please note that Stock Market Crashes are blank when there are no stock prices in time series. Also, the year of independence is included in the database, if the country went independent before 1800 , the whole series will be a column of $1 \mathrm{~s}$.

Country coverage: 70 countries

Time coverage: $1800-2010$

Frequency: Annual

\section{6. "Debt-to-GDP Ratios"}

Authors: Carmen M. Reinhart

Website: http://www.carmenreinhart.com/data/browse-by-topic/topics/9/

Description: The information covers annual data from as early as 1692 for the U.K. and 1719 for Sweden (depending on the country) to 2010 (updated with the World Bank's July 2010 Quarterly External Debt Statistics and individual mostly official country sources, as detailed for public debt). Each country has its own page with the underlying data from multiple sources (with their corresponding full bibliographical references). This source (partially) includes external gross central government debt/exports, total (domestic plus 
external) gross central government debt/GDP, total (domestic plus external) gross general government debt/GDP, and total (public plus private) gross external debt/GDP.

Notes for Researchers: The coverage of debt data varies from country to country due to data availability. The data source of each year has been included in the database and the compositions of the debt data for each country are also included in the database. Please notice that most of the data series are in percentage to GDP, but there are some series reported in percentage to GNP. This database extends the database extensively documented in Carmen Reinhart and Kenneth Rogoff's 2008 paper "This Time is Different: A Panoramic View of Eight Centuries of Financial Crisis," https://www.nber.org/papers/w13882. This paper, and their later 2009 book This Time is Different: Eight Centuries of Financial Folly, both contain extensive discussion of previously unexploited resources that allowed, for the first time, the construction of long-dated public debt series which had previously been available only for a few countries. Reinhart and Rogoff use their debt data series in "The Forgotten History of Domestic Debt," https:/www.nber.org/papers/w13946, (later published with minor revisions in 2011 in the Economic Journal, 121 (552), pp. 319-50), as well as in their 2011 paper, Carmen M. Reinhart and Kenneth Rogoff, "From Financial Crash to Debt Crisis," American Economic Review, 101, 1676-706.

https://scholar.harvard.edu/files/rogoff/files/from_financial_crash.pdf. Importantly, that paper also posted the debt to GDP time series https://scholar.harvard.edu/files/rogoff/files/53 data 0.xls. The data had earlier been posted in 2010. The data set is also used in Carmen M. Reinhart, Vincent R. Reinhart, and Kenneth S. Rogoff, 2012. "Public Debt Overhangs: Advanced-Economy Episodes since 1800," Journal of Economic Perspectives, 26 (3), pp. 69-86.

https://www.aeaweb.org/articles?id=10.1257/jep.26.3.69. The data, including not only debt/GDP Data going back to 1800 but associated interest rate series, is found at https://www.aeaweb.org/articles?id=10.1257/jep.26.3.69. Finally, a very early nascent version of the Reinhart-Rogoff debt database is employed in Carmen Reinhart, Kenneth Rogoff, and Miguel A. Savastano, 2003. "Debt Intolerance," Brookings Papers on Economic Activity, 1: 1-74. https://scholar.harvard.edu/files/rogoff/files/51 bpea2003.pdf.

Country coverage: 70 countries

Time coverage: $1692-2010$ (partial coverage)

Frequency: Annual

\section{7. "This Time Is Different: Eight Centuries of Financial Folly" (Princeton University Press, 2009)}

Authors: Carmen M. Reinhart and Kenneth S. Rogoff

Website: http://www.reinhartandrogoff.com/data/

Description: The database contains twelve datasets that authors prepared in the publication. It includes world crises indices, crises, debt to GDP ratios, exchange rates, gold standard dates, inflation, silver-based exchange rates, and other related datasets.

Notes for Researchers: This data source also provides all tables, figures, and raw data for the publication. The majority of the data series are updated to 2017. Importantly, the 
appendix to the 2009 book contains extensive discussion and documentation of sources to facilitate replication and extension.

Country coverage: Varies by dataset

Time coverage: 1800-2017 (Varies by dataset)

Frequency: Annual

18. "Managing the UK National Debt 1694-2018"

Authors: Andrew Scott

Website: http://users.ox.ac.uk/ exet2581/data/data.html

Description: The author compiled a bond-by-bond dataset for every individual bond issued by U.K. government. It provides monthly data series on quantity and market price for each bond from 1694 to 2018. For more details, please refer to the working paper available at: http://users.ox.ac.uk/ exet2581/wp/AEJMacro-2018-0263.R1 Ellison Scott manuscript.pdf

Country coverage: United Kingdom

Time coverage: 1694-2018

Frequency: Monthly

\section{B. Institutional Databases}

\section{9. "Debt Securities"}

Authors: Bank for International Settlements

Website: https://www.bis.org/statistics/secstats.htm?m=6\%7C33\%7C615

Description: This database covers borrowing activities in debt capital markets. Table $\mathrm{C} 1$ provides a summary of debt securities outstanding by sector (financial corporations, nonfinancial corporations, and general government) and residence (international/domestic markets). Table $\mathrm{C} 2$ provides more information on central government debt securities markets, broken down by instrument and maturity. Table C3 is a set of country tables which give the most detailed view on debt securities. It provides data series on net flows and amount outstanding by residence, sector, currency, instrument, and maturity.

Country coverage: Global (157 countries for table $\mathrm{C} 1$ and $\mathrm{C} 3,30$ countries for table $\mathrm{C} 2$ )

Time coverage: 1952-present (partial coverage from 1952 to 1970; better coverage after 1970)

Frequency: Quarterly

\section{0. "Sovereign Default"}

Authors: Bank of Canada

Website:_https://www.bankofcanada.ca/2018/07/staff-working-paper-2018-30/ 
Description: In order to measure the sovereign debt in default, the Bank of Canada has developed a comprehensive database of sovereign defaults. This database includes the total debt in default by creditor (IMF, IBRD, Paris Club, private creditors, FC bank loans, FC bonds, LC debts) and by debtor (advanced economies, emerging/frontier markets, HIPC countries).

Country coverage: 145 countries

Time coverage: 1960-2017

Frequency: Annual

\section{1. "Debt securities issuance and service by EU government"}

Authors: European Central Bank (ECB)

Website: http://sdw.ecb.europa.eu/reports.do?node=1000003848

Description: This report provides debt securities issuance and service statistics for the euro area and individual EU Member States. Data is further broken down by maturity, interest rate type (Fixed/Floating) and currency denomination (Euro/USD/GBP). More detailed securityby-security information is also available in the "Centralized Securities Database"

(https://sdw.ecb.europa.eu/browseExplanation.do?org.apache.struts.taglib.html.TOKEN=63c $99637 \mathrm{c} 7 \mathrm{e} 920605 \mathrm{bc} 134 \mathrm{df7}$ c4ba161\&df $=$ true \&ec $=\& \mathrm{dc}=\& \mathrm{oc}=\& \mathrm{pb}=\& \mathrm{rc}=\& D A T A S E T=0 \& \mathrm{re}$ moveItem $=$ \&removedItemList $=\&$ mergeFilter $=$ \&activeTab $=$ SHS\&showHide $=\& M A X \_D O W$ NLOAD_SERIES $=500 \&$ SERIES MAX_NUM $=50 \&$ node $=9691594$ )

Country coverage: $28 \mathrm{EU}$ countries

Time coverage: $2016-$ Present

Frequency: Annual; Quarterly/Monthly data available from 2018

\section{2. "Living with Debt: How to Limit Risks of Sovereign Finance?"}

Authors: Inter-American Development Bank (IDB)

Website: $\underline{\text { https://data.iadb.org/Datacatalog/Dataset\#DataCatalogID=7cm5-ndt4 }}$

Description: This database reports, in percent of GDP, primary deficit, interest payments, gross public debt, domestic public debt, external public debt (broken down further official and private creditors). It also reports, as a share of gross public debt, debt denominated in foreign currency and local currency.

Country coverage: 26 Latin-American countries

Time coverage: 1980-2013

Frequency: Annual (partial coverage)

\section{3. "Standardized Public Debt Database"}

Authors: Inter-American Development Bank (IDB)

Website: https://data.iadb.org/Datacatalog/Dataset\#DataCatalogID=3bvi-edbq 
Description: This database contains more than 190 public debt-related series. Among the more important variables are debt maturity, bank loans, debt issued in foreign/domestic currency, exchange rates, external/internal legislation debt, etc.

Notes for researchers: The time coverage of the database is from 2006 to 2016, but 200608 data are annual data, and semi-annual data are available from 2009 to 2016.

Country coverage: 26 Latin-American countries

Time coverage: $2 \mathrm{H} 2006-2 \mathrm{H} 2016$

Frequency: Semi-annual

\section{4. "Fiscal Monitor (FM)"}

Authors: International Monetary Fund (IMF)

Website: https://www.imf.org/en/Publications/FM/Issues/2019/03/18/fiscal-monitor-april$\underline{2019}$

Description: The Fiscal Monitor surveys and analyzes the latest public finance developments. It updates fiscal implications of the crisis and medium-term fiscal projections and assesses policies to put public finances on a sustainable footing. This database provides country specific data and projections for key fiscal variables (including public gross financing needs on table 1.3 and table 1.4). More data series are available from table A4 to table A25. More historical data are available from IMF Data Mapper (https://www.imf.org/external/datamapper/datasets/FM)

Country coverage: 115 countries (partial coverage based on data availability from country desks)

Time coverage: $2010-$ Present

Frequency: Annual

\section{5. "Global Debt Database"}

Authors: Samba Mbaye, Marialuz Moreno Badia, and Kyungla Chae, International Monetary Fund

Website: https://www.imf.org/en/Publications/WP/Issues/2018/05/14/Global-DebtDatabase-Methodology-and-Sources-45838

Description: The database covers 190 countries worldwide, including advanced economies emerging markets economies, and low-income countries and contains total gross debt information on private, household, non-financial corporate, central government, general government, non-financial public sector, and public sector.

Notes for Researchers: The coverage of debt data varies from country to country due to data availability. For certain sectors, such as the private sector, researchers have the flexibility to pursue for a longer time series (with a narrower definition which only includes debt securities and loans) or a wider definition of debt (includes all instruments) but with shorter time series.

Country coverage: 190 countries 
Time coverage: 1950-2017 (partially covered); updated annually with lag $\mathrm{T}+12$

Frequency: Annual

\section{6. "International Financial Statistics (IFS)"}

Authors: International Monetary Fund (IMF)

Website: https://data.imf.org/?sk=4C514D48-B6BA-49ED-8AB9-52B0C1A0179B

Description: IFS provides several high-level debt related data series, namely: overall external debt (stock and flow); overall debt position by sector (government; central bank; depository corporations; other depository corporations; other financial corporations; nonfinancial corporations). Some high-level debt holder information is also available for certain countries. (e.g., central bank liabilities to other depository corporations). But data availability varies by country.

Country coverage: Global (most IMF member countries)

Time coverage: $2000-$ Present

Frequency: Annual/Quarterly/Monthly

\section{7. "Public Sector Balance Sheet (PSBS)"}

Authors: International Monetary Fund (IMF)

Website: https://data.imf.org/psbs

Description: This database provides comprehensive estimates of public sector assets and liabilities for 38 countries. This database is compiled largely based on IMF's Government Finance Statistics database and Monetary and Financial Statistics database. Where these data fail to cover all categories of assets and liabilities, they are complemented by other data reported by statistical authorities at the national level, other international organization or staff estimates. Data is reported in both national currency and percent of GDP.

Country coverage: 38 countries

Time coverage: $2000-$ Present

Frequency: Annual

\section{8. "World Economic Outlook (WEO)"}

Authors: International Monetary Fund (IMF)

Website: https://www.imf.org/external/ns/cs.aspx?id=28

Description: WEO provides several overall public debt related data series, namely: general government gross debt (by domestic currency/foreign currency); general government debt service; general government gross debt as a percent of fiscal year GDP; general government net debt; general government net debt as a percent of fiscal year GDP. WEO only provides high-level government debt data. It does not have further information on private debt, debt holder information, etc.

Country coverage: Global (most IMF member countries) 
Time coverage: 1980-present (Partial coverage from 1980 to 2000; most countries covered after 2000)

Frequency: Annual

\section{9. "General Government Debt"}

Authors: Organization for Economic Co-operation and Development (OECD)

Website: https://data.oecd.org/gga/general-government-debt.htm

Description: This database provides data series on general government debt-to-GDP ratio. It also covers a wider range of data series on government finance, such as spending (by central/general government), revenue, deficit, production cost.

Country coverage: OECD countries

Time coverage: 1995-2017

Frequency: Annual

\section{0. "International Debt Statistics (IDS)"}

Authors: World Bank (WB)

Website: https://datacatalog.worldbank.org/dataset/international-debt-statistics

Description: IDS is one of the most detailed databases concerning about external debt. It includes over 200 time series. It provides detailed information on debt outstanding, debt service, currency composition, creditors, terms, interest, amortization, arrears, etc. It provides a relatively comprehensive picture of countries' external debt with a very granular level of breakdowns. Other than debt data, IDS also includes data series about balance of payment and major financial indicators.

Notes for researchers: This database has a focus on emerging and low-income countries; most advanced countries are missing from this database. This database also does not have any information on domestic debt.

Country coverage: 121 (mostly low- and middle-income countries)

Time coverage: $1970-2016$

Frequency: Annual

\section{1. “Quarterly External Debt Statistics (QEDS)"}

Authors: World Bank (WB) \& International Monetary Fund (IMF)

Website: http://datatopics.worldbank.org/debt/qeds;

http://databank.worldbank.org/data/reports.aspx? source=quarterly-external-debtstatistics/sdds-(new)

Description: This database aims to provide quarterly data on breakdowns of the total gross external debt position by sector, maturity, and instrument. Classifications and definitions are in line with the Guide for Compilers and Users (2013 EDS Guide) and Sixth Edition of Balance of Payments and International Investment Position Manual (BPM6). Data are 
published individually by countries that subscribe to the IMF's Special Data Dissemination Standard (SDDS). Other than the core set of data series, countries are also encouraged to provide data on domestic-foreign currency breakdown; forward debt service schedule, and principal and interest payments due in one year or less. But coverage for those data series varies by country.

Country coverage: 40 developing and low-income countries

Time coverage: 1998Q1-Present

Frequency: Quarterly

\section{2. "Quarterly Public Sector Debt (QPSD)"}

Authors: World Bank (WB) \& International Monetary Fund (IMF)

Website: https://datacatalog.worldbank.org/dataset/quarterly-public-sector-debt

Description: This database aims to provide detailed quarterly data on breakdowns of public sector debt position by sector (General government; Central government; Budgetary central government; Nonfinancial public corporations and Financial public corporations), maturity and instrument. The database is updated quarterly and within one month of the end of a quarter. The participation of countries in this centralized database is voluntary and data coverage varies by country.

Country coverage: 40 developing and low-income countries

Time coverage: 1995Q1-Present

Frequency: Quarterly 